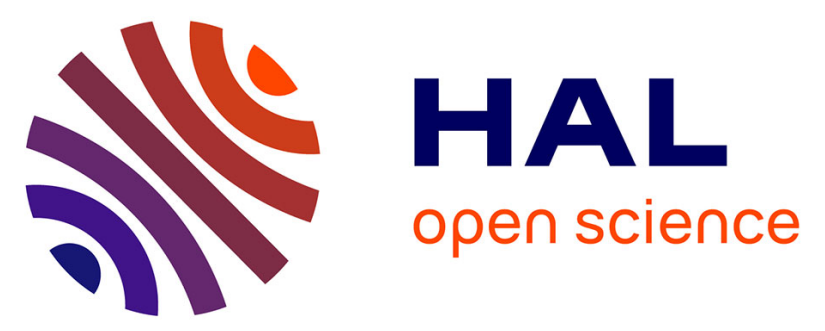

\title{
Post-weaning multisystemic wasting syndrome (PMWS) clinical expression under field conditions is modulated by the pig genetic background
}

Sergio López-Soria, Miquel Nofrarías, Maria Calsamiglia, Anna Espinal, Oliver Valero, Humberto Ramírez-Mendoza, Almudena Mínguez, José M. Serrano, Óscar Marín, Antonio Callén, et al.

\section{To cite this version:}

Sergio López-Soria, Miquel Nofrarías, Maria Calsamiglia, Anna Espinal, Oliver Valero, et al.. Post-weaning multisystemic wasting syndrome (PMWS) clinical expression under field conditions is modulated by the pig genetic background. Veterinary Microbiology, 2011, 149 (3-4), pp.352. 10.1016/j.vetmic.2010.12.009 . hal-00683506

\section{HAL Id: hal-00683506 https://hal.science/hal-00683506}

Submitted on 29 Mar 2012

HAL is a multi-disciplinary open access archive for the deposit and dissemination of scientific research documents, whether they are published or not. The documents may come from teaching and research institutions in France or abroad, or from public or private research centers.
L'archive ouverte pluridisciplinaire HAL, est destinée au dépôt et à la diffusion de documents scientifiques de niveau recherche, publiés ou non, émanant des établissements d'enseignement et de recherche français ou étrangers, des laboratoires publics ou privés. 


\section{Accepted Manuscript}

Title: Post-weaning multisystemic wasting syndrome (PMWS) clinical expression under field conditions is modulated by the pig genetic background

Authors: Sergio López-Soria, Miquel Nofrarías, Maria Calsamiglia, Anna Espinal, Oliver Valero, Humberto

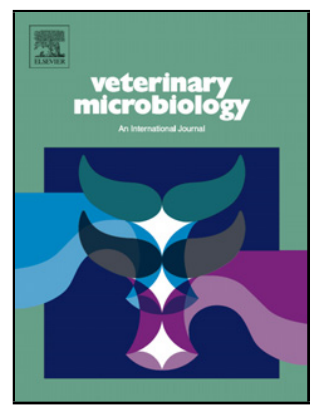

Ramírez-Mendoza, Almudena Mínguez, José M. Serrano, Óscar Marín, Antonio Callén, Joaquim Segalés

PII:

DOI:

S0378-1135(10)00582-1

Reference: doi:10.1016/j.vetmic.2010.12.009

To appear in: VETMIC 5121

Received date: VETMIC

Revised date:

$$
\text { 29-8-2010 }
$$

Accepted date:

Please cite this article as: López-Soria, S., Nofrarías, M., Calsamiglia, M., Espinal, A., Valero, O., Ramírez-Mendoza, H., Mínguez, A., Serrano, J.M., Marín, Ó., Callén, A., Segalés, J., Post-weaning multisystemic wasting syndrome (PMWS) clinical expression under field conditions is modulated by the pig genetic background, Veterinary Microbiology (2010), doi:10.1016/j.vetmic.2010.12.009

This is a PDF file of an unedited manuscript that has been accepted for publication. As a service to our customers we are providing this early version of the manuscript. The manuscript will undergo copyediting, typesetting, and review of the resulting proof before it is published in its final form. Please note that during the production process errors may be discovered which could affect the content, and all legal disclaimers that apply to the journal pertain. 
$24{ }^{*}$ Corresponding Author. Tel.: +34 935814495; fax: +34 935814490. field conditions is modulated by the pig genetic background Marín $^{\text {d }}$, Antonio Callén e, Joaquim Segalés ${ }^{\text {a,f }}$ Autònoma de Barcelona, 08193 Bellaterra, Barcelona, Spain ${ }^{b}$ Servei d'Estadística, Universitat Autònoma de Barcelona, Barcelona, Spain México, Mexico City, 04510, Mexico

${ }^{d}$ Swine Veterinarians, Valencia, Spain ${ }^{e}$ Merial Laboratorios, Barcelona, 08014, Spain 08193 Bellaterra, Barcelona, Spain

25 E-mail address: sergio.lopez@cresa.uab.cat (S. López-Soria)

Post-weaning multisystemic wasting syndrome (PMWS) clinical expression under

Sergio López-Soria ${ }^{a}{ }^{*}$, Miquel Nofrarías ${ }^{\mathrm{a}}$, Maria Calsamiglia ${ }^{\mathrm{a}}$, Anna Espinal $^{\mathrm{b}}$, Oliver Valero $^{\text {b }}$, Humberto Ramírez-Mendoza ${ }^{\mathrm{c}}$, Almudena Mínguez ${ }^{\mathrm{d}}$, José M. Serrano ${ }^{\mathrm{d}}$, Óscar

${ }^{a}$ Centre de Recerca en Sanitat Animal (CReSA), UAB-IRTA, Campus de la Universitat ${ }^{c}$ Facultad de Medicina Veterinaria y Zootecnia. Universidad Nacional Autónoma de

${ }^{f}$ Departament de Sanitat i Anatomia Animals, Universitat Autònoma de Barcelona, 
ABSTRACT

Post-weaning multisystemic wasting syndrome (PMWS) is a worldwide

distributed disease of multifactorial origin and porcine circovirus type 2 (PCV2) has

been identified as its essential infectious aetiology. Pig genetic background has been pointed to influence disease expression. In the present study, three different boar lines, namely A (100\% Pietrain), B (50\% Large White x 50\% Pietrain) and C (25\% Large

White $\mathrm{x} 75 \%$ Duroc), were used to inseminate sows from the same genetic line $(37.5 \%$

Large White x 37.5\% Duroc x 25\% Landrace) located on two PMWS-affected farms

(farm-1 and farm-2). The PMWS clinical expression of their offspring was studied from

weaning to slaughter, evaluating three parameters: total post-weaning mortality (PWM),

PWM associated to PMWS (PMWS-PWM) and body weight (BW) evolution. The effect of other variables potentially related with PMWS, including sow and piglet PCV2 exposure, sow parity, piglet gender and piglet BW at weaning, were also considered in the study design. Overall, a total of 6.5\% PWM and 4.3\% PMWS-PWM occurred in the monitored farms. Pigs from boar line $\mathrm{C}$ showed the highest PWM (16.3\%) and PMWSPWM (12.4\%), and the lowest BW; pigs from boar line A showed the lowest PWM $(1.8 \%)$ and the highest BW. Furthermore, PWM was also higher in piglets from farm-2 and from multiparous sows. In farm-2, PMWS-PWM was higher in piglets from multiparous sows. Finally, BW was influenced by interactions between genetics and both farm and pig age, and was lower in piglets from farm-2. This study represents a consistent observation of the genetic background effect on PMWS clinical expression under field conditions. 
50 Key Words: Genetics, Pig, Porcine circovirus type 2, Post-weaning multisystemic

51 wasting syndrome.

52

\section{Introduction}

54

Porcine circovirus type 2 (PCV2) is found worldwide in pigs and has been

linked to several pathological conditions collectively named porcine circovirus diseases

(PCVD) (Segalés et al., 2005). The most economically important PCVD is post-

weaning multisystemic wasting syndrome (PMWS), which results in losses of $€ 900$

million per year in the European Union (Armstrong and Bishop, 2004).

60

Infection of pigs with PCV2 and other infectious/non-infectious triggers are required for PMWS to occur (Segalés et al., 2005). Evaluation of the role of these other triggers is essential in order to understand the pathogenesis of PMWS. Several studies have linked PMWS expression to management measures, presence of concurrent viral infections, stimulation of the immune system, PCV2 viraemia and low serological titres to PCV2 of the sow at farrowing, nutrition, male castration and lower piglet weight at weaning (Segalés et al., 2005).

Farmers and veterinarians in the field have suggested that different pig breeds or 70 genetic lines have different susceptibilities to PMWS. Similar effects have been 71 previously demonstrated for other diseases, including bacterial (Michaels et al., 1994; 72 Wigley, 2004), parasitic (Reiner et al., 2002a) and viral (Depner et al., 1997; Reiner et

73 al., 2002b; Vincent et al., 2006) diseases. Preliminary experimental studies have 74 suggested a higher susceptibility to PCV2-associated lesions and even on PMWS 
75 development of Landrace pigs compared to Duroc, Large White and Pietrain pigs

76 (Opriessnig et al., 2006, 2009). Experiences in the field have reported a significantly

77 less often occurrence of clinical signs resembling PMWS in pure bred conventional

78 Hampshire boars than in pure bred conventional Yorkshire or Landrace boars (Wallgren

79 et al., 2009). However, the introduction of a terminal Pietrain boar onto affected farms

80 showed no effect on PMWS expression (Rose et al., 2005). Besides these preliminary

81 studies minimal scientific work has so far been focused on the relationship between

82 genetics and PMWS development. The objective of the present study was to compare

83 the effect of 3 different genetic boar lines on the expression of PMWS in their offspring.

2. Materials and methods

86

Animal care and use conformed to the European Union guidelines and Good Clinical Practice.

89

90

The study was carried out in 2 almost identical 5000-sow farms (farm-1 and

91 farm-2) separated by $300 \mathrm{~m}$. Farm-1 and farm-2 belonged to the same producer company, which had a multi-site production system that used the same sow genetic line (37.5\% Large White x 37.5\% Duroc x 25\% Landrace) across all sites. Farms were 94 seronegative to porcine reproductive and respiratory syndrome (PRRSV) and

95 Aujeszky's disease virus (ADV), and no evidence of porcine parvovirus (PPV) 96 circulation was found in a subsample of 90 piglets from the studied batches (data not 97 shown). Post-weaning mortality in the year before study start ranged from 4 to $8 \%$ in both farms and was mainly attributed to PMWS, according to previous diagnostic analyses performed in the farms. 
102 Pietrain) and C (25\% Large White x 75\% Duroc), were used for artificial insemination.

103 Fifteen A, eight B, and four C boars were used. Sow insemination with each boar line 104 was assigned randomly. Each sow was not always inseminated with semen from the 105 same boar in repeated inseminations, but the boars were always from the same genetic 106 line. A total of 63 pregnant sows was obtained on farm-1 (24 pregnant from A boars, 20 107 from B boars and 19 from $\mathrm{C}$ boars) On farm-2 the figures were 67 pregnant sows (29 A,

$10823 \mathrm{~B}$ and $15 \mathrm{C}$ ). Sows were randomly placed in the farrowing facilities in both farms

109 taking into account that approximately one third of sows inseminated with each boar

110 line had to be present in each room (there were three rooms per farm). No cross111 fostering was allowed.

Semen (diluted for insemination and non-diluted from direct extraction) and

114 serum samples were collected from boars at the moment of the semen extraction. Serum 115 samples from sows were collected 1 week before farrowing.

A total of 1062 piglets (517 from farm-1 and 545 from farm-2) were obtained and ear-tagged before entering the nursery period ( 3 weeks of age) and monitored until

119 the end of the fattening period (21 weeks of age). Piglet distribution by farm, genetic

120 background, gender and sow parity is shown in Table 1. Sow parity was categorized as

1211 or $>1$ farrowings (Calsamiglia et al., 2007). Nursery pigs (3 to 10 weeks of age) from

122 farm-1 and farm-2 were placed in the same nursery building but in separate rooms (two rooms per group). Fattening pigs (from 10 weeks of age to slaughter) from farm-1 were

124 placed in pens located in front of those of farm-2 from the same room and farm. All 
125 pens in both the nursery and fattening units contained pigs from all three genetic

126 backgrounds.

age; all dead pigs during this period were necropsied and tissue samples (mesenteric

130 lymph node and lung) collected. A subpopulation of 207 piglets was randomly selected, blocked by genetic background, farm, sow of origin and sex (33 to 36 pigs for each genetic background and farm); these pigs were bled at 3 weeks of age and weighed at 3 , 9,15 and 21 weeks of age.

\subsection{Laboratory Analyses}

A standard polymerase chain reaction (PCR) method to detect PCV2 (Quintana

et al., 2002) was performed on serum samples from sows and piglets and serum, diluted and non-diluted semen from boars. An immunoperoxidase monolayer assay (IPMA)

140 was used to detect PCV2 antibodies (Rodríguez-Arrioja et al., 2000) in sera from boars,

141 sows and piglets. Antibody titres were classified as negative or low titre $(<1: 320)$ or 142 medium to high titre $(\geq 1: 320)$ (Rodríguez-Arrioja et al., 2000). Mesenteric lymph node

143 and lung samples collected from necropsied pigs were fixed by immersion in $10 \%$

144 buffered neutral formalin and routinely processed for histopathology. The presence of 145 PCV2 in these tissues was detected using an in situ hybridization technique (Rosell et 146 al., 1999). A pig was considered as suffering from PMWS when moderate to severe 147 lymphocyte depletion and histiocytic infiltration were found in lymphoid tissues associated with moderate to high amount of PCV2 (Segalés, 2002). 
PMWS expression was evaluated using 3 parameters: body weight (BW) at 3, 9,

15315 and 21 weeks of age, total post-weaning mortality (PWM), and PWM due to PMWS

154 (PMWS-PWM). Total PWM, which includes non-PMWS-related mortality, was

155 considered as a relevant production parameter because of the reported synergism

156 between PMWS and other causes of mortality (Segalés et al., 2005).

Two logistic regression models (Hosmer and Lemeshow, 2000) were established to evaluate both PWM and PMWS-PWM, including the sow as a random effect. A

160 longitudinal linear mixed model with repeated measures (Verbeke and Molenberghs,

161 1997) was performed to analyze BW. Covariates included in all models were genetic

162 background, farm, sow presence of PCV2 viraemia and antibody titre at farrowing, sow

163 parity, piglet's sex and BW, PCV2 infectious status and PCV2 antibodies at 3 weeks of

164 age. Interactions with farm were also included. The sow was included as a random 165 effect.

All results were obtained using GLIMMIX and MIXED procedures of the SAS System V.9.1 (SAS Institute Inc.). Significance level was fixed at 5\%.

\section{Results}

PCV2 was not detected in any boar and sow serum sample, or any semen sample. The proportion of sows with medium to high PCV2 antibody titres as well as

174 the proportion of piglets that came from them is shown in Table 1. 
177 pig at 20 weeks), and from 9 to 15 weeks of age on farm-2. Further information on PWM and PMWS-PWM expression by farm and genetic background is shown in Table

1. The antibody titres and BW changes of the 207 monitored piglets are also shown in

180 Table 1.

181

Logistic regression models showed a significant effect of genetic background $(P$ $<0.001)$, farm $(P=0.001)$ and parity $(P=0.038)$ on total PWM. Specifically, PWM was more likely in piglets from $\mathrm{C}$ boars than both $\mathrm{A}\left(\mathrm{OR}=11.95, \mathrm{CI}_{\mathrm{OR}}=5.10\right.$ to 28.02) and $\mathrm{B}\left(\mathrm{OR}=4.42, \mathrm{CI}_{\mathrm{OR}}=2.29\right.$ to 8.55$)$. Also, $\mathrm{PWM}$ was more likely for $\mathrm{B}$ than for $\mathrm{A}$ $\left(\mathrm{OR}=2.70, \mathrm{CI}_{\mathrm{OR}}=1.08\right.$ to 6.77$)$ backgrounds. In addition, PWM was more likely in piglets from farm- 2 than farm- $1\left(\mathrm{OR}=2.88, \mathrm{CI}_{\mathrm{OR}}=1.56\right.$ to 5.33$)$. Finally, $\mathrm{PWM}$ was more likely in piglets from multiparous than primiparous sows $\left(\mathrm{OR}=2.18, \mathrm{CI}_{\mathrm{OR}}=1.04\right.$ to 4.54$)$.

190

A significant effect of genetic background $(P<0.001)$ and a farm and parity interaction $(P=0.048)$ on PMWS-PWM was obtained. PMWS-PWM was more likely for piglets from $\mathrm{C}$ boars than both $\mathrm{A}\left(\mathrm{OR}=15.55, \mathrm{CI}_{\mathrm{OR}}=4.92\right.$ to 43.06$)$ and $\mathrm{B}(\mathrm{OR}=8.26$, $\mathrm{CI}_{\mathrm{OR}}=3.19$ to 21.39 ). An effect of sow parity was only observed on farm-2, where PMWS-PWM was more likely in piglets from multiparous than primiparous sows $\left(\mathrm{OR}=6.86, \mathrm{CI}_{\mathrm{OR}}=1.35\right.$ to 34.94$)$. background $(P<0.001)$, farm $(P=0.003)$, age $(P<0.001)$, genetics and farm interaction 
$200(P=0.044)$ and genetics and age interaction $(P=0.004)$. Piglets from farm-2 showed

201 lower weights than those from farm-1. Detailed results from the longitudinal mixed 202 model are shown in Table 2.

203

\section{4. Discussion}

Most evidence of the effect of genetic background on PMWS susceptibility has come from the experimental side (Opriessnig et al., 2006, 2009). These studies included

a limited number of pigs and used pure-bred animals, which is unusual under field conditions. Furthermore, few studies have been performed in the field in regards

210 genetics and PMWS occurrence, where no apparent relationship between boar genetic

211 background and disease expression was observed in the offspring (Rose et al., 2005) or minimal information was available when genetic background susceptibility was observed (Wallgren et al., 2009).

This study aimed to assess whether clinical expression of PMWS was influenced

215 by genetic background. Three different boar lines that swine producers had suggested as

216 having different PMWS outcome severity in their offspring were used. Using BW,

217 PMWS-PWM and total PWM as measures of PMWS expression, this study confirmed

218 those suggestions. It also confirmed that other factors, such as farm of origin, sow parity 219 and piglet age, were associated with the effects of PMWS.

Several measures to diminish potential biases that may occur under field conditions were adopted for this study. Two sow farms which were located together, with the same farm management and characteristics and sow genetic background were used. Piglets were reared on the same nursery and fattening farms, so were kept under 
the most similar environmental conditions. Furthermore, any potential biases due to

226 concurrent diseases are unlikely in this study as PPV, PRRSV and ADV, three viruses reported to be related to clinical expression of PMWS (Ellis et al., 2004), did not circulate in the studied batches. In addition, total PWM was mainly associated to PMWS based on pathological findings. Finally, other factors, i.e. sow and pig PCV2

230 infectious status and antibody titre, sow parity, piglet gender and weaning BW, that 231 could influence PMWS expression were also studied.

PCV2 infectious status of sows, boars and weaned piglets was assessed as PCV2 status has a significant effect on litter mortality in PMWS-affected farms (Calsamiglia et al., 2007), and the earlier the pig is infected with PCV2, the higher the risk of suffering from PMWS (Rose et al., 2003; López-Soria et al., 2005). The fact that no sample demonstrated PCV2 infection reinforces the role of the genetic background as a risk factor for PMWS, and suggests that it was probably the most significant one on the farms in this study.

Significant differences between genetic backgrounds were observed in the present study. Piglets from C boars were the most affected, showing lower BW and higher rates of PWM and PMWS-PWM than those from A and B boars. Piglets from A

244 boars had higher BW at slaughter age and lower PWM compared to those from the 245 other two studied boar lines. These findings are in agreement with the experimental 246 study by Opriessnig et al., (2009) who reported that Landrace piglets developed more severe PMWS-like lesions than Pietrain. However they contradict a previous French field study which did not find any difference when the usual terminal boar breed was replaced by Pietrain (Rose et al., 2005). These results may seem contradictory; however, 
250 differences in study design may be the cause of these inconsistencies. Moreover, such

251 differences could be attributed to the fact that different Pietrain genetic lines were used

252 in different studies, and it is possible that PMWS genetic susceptibility/resistance might

253 be related to particular genetic lines rather than breeds or potential allele variants within 254 lines.

The critical period for BW differences between lines was between 15 and 21 weeks of age, just after the PMWS outbreak. The significantly higher weights found in piglets from A boars at 21 weeks of age was noteworthy because Duroc and Large White breeds are expected to show better growth rates than Pietrain (Whittemore, 1998). This result thus supports the idea of a significant impact of PMWS on average daily gain, and is consistent with the improvement of growth rate in pigs vaccinated against PCV2 (Fachinger, et al., 2008; Horlen et al., 2008; Kixmöller et al., 2008).

The link reported here (farm-2) between sow parity and PMWS-associated mortality, and also reported in another study (Armstrong and Bishop, 2004), seems to be a controversial point since others did not find it (Madec et al., 2000; Calsamiglia et al., 2007). In fact, piglets from multiparous sows showed higher total PWM on both farms, but it was only higher for PMWS-PWM on farm-2. There are no apparent consistent explanations for these discrepancies and they may be attributable to the multifactorial nature of PMWS, in which unknown triggering factors may account for specific farm differences.

274 development. PCV2 maternally derived antibodies seem to protect against piglet 
mortality based on field (Allan et al., 2002; Calsamiglia et al., 2007; Grau-Roma et al., 276 2009) and experimental (Allan et al., 2002; McKeown et al., 2005; Ostanello et al., 277 2005) data. However, no effect of sow IPMA antibody titre at farrowing or piglet titre at

2783 weeks of age in PMWS-PWM were observed in the present study, probably because 279 of the very high percentage of piglets coming from sows with medium to high PCV2 280 antibody titres. Curiously, piglets from A boars experienced lower total PWM and 281 PMWS-PWM despite showing the lowest proportion of piglets with medium to high 282 PCV2 antibody titres in farm-1 and the highest in farm-2. Again, PCV2 antibody titres in sows and piglets should be considered as elements that modulate PMWS expression within the context of a multifactorial disease. Therefore, not all the risk factors so far identified for PMWS have an equal on different farms with different production scenarios.

PMWS-PWM records in the present study were very similar between females and males, being 4.3 and $4.4 \%$, respectively. Previous studies have found that castrated males had higher PMWS-associated mortality than females (Corrégé et al., 2001; Rodríguez-Arrioja et al., 2002). In the present study males were not castrated, suggesting that physiological and behavioural changes or surgical complications due to male castration (Prunier et al., 2006) may be a risk factor for PMWS occurrence. reported (Corrégé et al., 2001).This association between BW and PMWS has not been observed in the present study, although disease has been measured with different parameters in both studies. 


\section{Conclusion}

301

302

This study represents a consistent observation of the genetic background effect

on PMWS clinical expression under field conditions. However, such study cannot be

304 used to determine if the observed effect was an effect of breed (such as a protective

305 effect for Pietrain or susceptibility in Duroc), particular boar lines or individuals (only 4

306 boars from genetic line $\mathrm{C}$ were used in the study, so the effect of each individual was

307 higher than in the other genetic lines). Furthermore, it cannot be concluded that this

308 effect would appear if a different sow genetic line was used. Further studies are needed

309 to elucidate the exact role by which porcine genetics affect susceptibility/resistance to

310 PMWS.

311

312 Acknowledgements

313

This work was partly funded by the Special Action AGL2002-10252-E from the

315 Spanish Government. The Spanish Government had no involvement in the study design,

316 in the collection, analysis or interpretation of data, in the writing of the manuscript, or in

317 the decision to submit the manuscript for publication. The authors are grateful to M.

318 Pérez and E. Huerta from CReSA for the technical assistance, and all the colleagues and

319 farmers who collaborated during the farm work.

320

321 Conflict of interest statement

322 
324 other people or organisations that could inappropriately influence or bias the content of 325 the paper.

\section{References} development of post-weaning multisystemic wasting syndrome (PMWS): experimental infections and a field study. Pig J. 50, 59-67.

Armstrong, D., Bishop, S., 2004. Does genetics or litter effect influence mortality in

PMWS. In: Proceedings of the $18^{\text {th }}$ International Pig Veterinary Society Congress, Hamburg, Germany, p.809.

Calsamiglia, M., Fraile, L., Espinal, A., Cuxart, A., Seminati, C., Martín, M., Mateu,

340 E., Domingo, M., Segalés. J., 2007. Sow porcine circovirus type 2 (PCV2) status 341 effect on litter mortality in postweaning multisystemic wasting syndrome (PMWS). $342 \quad$ Res. Vet. Sci. 82(3), 299-304.

344 Corrégé, I., Pirouelle, H., Gaudré, D., Le Tiran., M.H., 2001. La Maladie de 345 l'Amaigrissement du Porcelet (MAP). In: 33èmes Journées de la Recherche Porcine 346 en France, Paris, France, pp.283-290. 
Depner, K.R., Hinrichs, U., Bickhardt, K., Greiser-Wilke, I., Pohlenz, J., Moennig, V., Liess, B., 1997. Influence of breed-related factors on the course of classical swine fever virus infection. Vet. Rec. 140(19), 506-507. 2004. Porcine circovirus-2 and concurrent infections in the field. Vet. Microbiol. 98, $159-163$.

Fachinger, V., Bischoff, R., Jedidia, S.B., Saalmüller, A., Elbers, K., 2008. The effect of vaccination against porcine circovirus type 2 in pigs suffering from porcine respiratory disease complex. Vaccine. 26(11), 1488-99

Grau-Roma, L., Hjulsager, C.K., Sibila, M., Kristensen, C.S., López-Soria, S.,Enøe, porcine circovirus type 2 (PCV2) in pigs from post-weaning multisystemic wasting syndrome (PMWS) affected farms in Spain and Denmark. Vet. Microbiol. 135(3-4), $272-282$

Horlen, K.P, Dritz, S.S., Nietfeld, J.C., Henry, S.C., Hesse, R.A., Oberst, R., Hays, M., Anderson, J., Rowland, R.R., 2008. A field evaluation of mortality rate and growth performance in pigs vaccinated against porcine circovirus type 2. J. Am. Vet. Med. Assoc. 232(6), 906-912. 

Inter-science, Massachusets. V., 2008. Reduction of PMWS-associated clinical signs and co-infections by vaccination against PCV2. Vaccine. 26(27-28), 3443-51. 69(1-2), 97-107.

Madec, F., Eveno, E., Morvan, P., Hamon, L., Blanchard, P., Cariolet, R., Amenna, multisystemic wasting syndrome (PMWS) in pigs in France: clinical observations from follow-up studies on affected farms. Livest. Prod. Sci. 63, 223-233.

McKeown, N.E., Opriessnig, T., Thomas, P., Guenette, D.K., Elvinger, F., Fenaux, Lab. Immunol. 12(11), 1347-1351.

Michaels, R.D., Whipp, S.C., Rothschild, M.F., 1994. Resistance of Chinese Vet. Res. 55, 333-338. 
398 Opriessnig, T., Fenaux, M., Thomas, P., Hoogland, M.J., Rothschild, M.F., Meng, 399 X.J., Halbur, P. G., 2006. Evidence of breed-dependent differences in susceptibility 400 to porcine circovirus type-2-associated disease and lesions. Vet. Pathol. 43(3), 281401293.

402

403 Opriessnig, T., Patterson, A.R., Madson, D.M., Pal, N., Rothschild, M., Kuhar, D., 404 Lunney, J.K., Juhan, N.M., Meng, X.J., Halbur, P. G., 2009. Difference in severity 405 of porcine circovirus type two-induced pathological lesions between Landrace and 406 Pietrain pigs. J. Anim. Sci. 87(5), 1582-1590.

407

408 Ostanello. F, Caprioli, A., Di Francesco, A., Battilani, M., Sala, G., Sarli, G., 409 Mandrioli, L., McNeilly, F., Allan, G.M., Prosperi, S., 2005. Experimental infection 410 of 3-week-old conventional colostrum-fed pigs with porcine circovirus type 2 and 411 porcine parvovirus. Vet. Microbiol. 108(3-4), 179-186.

413 Prunier, A., Bonneau, M., von Borell, E.H., Cinotti, S., Gunn, M., Fredriksen, B., 414 Giersing, M., Morton, D.B., Tuyttens, F.A.M., Velarde, A., 2006. A review of the 415 welfare consequences of surgical castration in piglets and the evaluation of non416 surgical methods. Anim. Welf. 15, 277-289.

418 Quintana, J., Balasch, M., Segalés, J., Calsamiglia, M., Rodríguez-Arrioja, G.M., 419 Plana-Durán, J., Domingo, M., 2002. Experimental inoculation of porcine 420 circoviruses type 1 (PCV1) and type 2 (PCV2) in rabbits and mice. Vet. Res. 33(3), 421 $229-37$. 
423 Reiner, G., Melchinger, E., Kramarova, M., Pfaff, E., Büttner, M., Saalmüller, A., 424 Geldermann, H., 2002b. Detection of quantitative trait loci for 425 resistance/susceptibility to pseudorabies virus in swine. J. Gen. Virol. 83, 167-172. A., Daugschies, A., Gelder-mann, H., 2002a. Variation in clinical and parasitological traits in Pietrain and Meishan pigs infected with Sarcocystis miescheriana. Vet. Parasitol. 106, 99-113.

Rodríguez-Arrioja, G.M., Segalés, J., Balasch, M., Rosell, C., Quintana, J., Folch, J.M., Plana-Durán, J., Mankertz, A., Domingo, M., 2000. Serum antibodies to porcine circovirus type 1 and type 2 in pigs with and without PMWS. Vet. Rec. 146(26), 762-764.

436

Rodríguez-Arrioja, G.M., Segalés, J., Calsamiglia, M., Resendes, A.R., Balasch, M., Plana-Duran, J., Casal, J., Domingo, M., 2002. Dynamics of porcine circovirus type 2 infection in a herd of pigs with postweaning multisystemic wasting syndrome. Am. J. Vet. Res. 63, 354-357.

Rose, N., Larour, G., Le Diguerher, G., Eveno, E., Jolly, J. P., Blanchard, P., Oger, A., Le Dimna, M., Jestin, A., Madec, F., 2003. Risk factors for porcine postweaning multisystemic wasting syndrome (PMWS) in 149 French farrow-to-finish herds. Prev. Vet. Med. 61, 209-225. 
Rose, N., Abhervé-Guéguen, A., Le Diguerher, G., Eveno, E., Jolly, J. P.,

448 Blanchard, P., Oger, A., Jestin, A., Madec, F., 2005. Effect of the Pietrain breed

449 used as terminal boar on Post-weaning Multisystemic Wasting Syndrome (PMWS)

$450 \quad$ in the offspring in four PMWS-affected farms. Livest. Prod. Sci. 95(3), 177-186.

Rosell, C., Segalés, J., Plana-Durán, J., Balasch, M., Rodríguez-Arrioja, G.M., Kennedy, S., Allan, G.M., McNeilly, F., Latimer, K.S., Domingo, M., 1999. Pathological, immunohistochemical, in-situ hybridization studies of natural cases of postweaning multisystemic wasting syndrome (PMWS) in pigs. J. Comp. Pathol. 120(1), 59-78.

Segalés, J., 2002. Update on postweaning multisystemic wasting syndrome and porcine dermatitis and nephropathy syndrome diagnostics. J. Swine Health Prod. 10, 277-281.

Segalés, J., Allan, G.M., Domingo, M., 2005. Porcine circovirus diseases. Anim. Health Res. Rev. 6, 119-142.

Verbeke, G., Molenberghs, G., 1997. Linear mixed models in practice: A SAS oriented approach. Lecture notes in statistics 126. Springer-Verlag, New York.

Vincent, A.L., Thacker, B.J., Halbur, P. G., Rothschild, M.F., Thacker, E.L., 2006.

469 An investigation of susceptibility to porcine reproductive and respiratory syndrome 470 virus between two genetically diverse commercial lines of pigs. J. Anim. Sci. 84(1), 471 $49-57$. 
473 Wallgren, P., Brunborg, I.M., Blomqvist, G., Bergström, G., Wikström, F., Allan,

474 G., Fossum, C., Jonassen, C.M., 2009. The index herd with PMWS in Sweden:

475 presence of serum amyloid A, circovirus 2 viral load and antibody levels in healthy

476 and PMWS-affected pigs. Acta Vet Scand 51:13.

477

478 Whittemore, C.T., 1998. The Science and Practice of Pig Production. 2nd ed. $479 \quad$ Blackwell Science Ltd., Osney Mead, OX, pp. 172-179

480

481 Wigley, P., 2004. Genetic resistance to Salmonella infection in domestic animals. $482 \quad$ Res. Vet. Sci. 76(3), 165-169. 
Table 1. Descriptive statistics on explanatory and response variables from piglets included in the study.

\begin{tabular}{|c|c|c|c|c|c|c|}
\hline Variable & \multicolumn{3}{|c|}{ Farm-1 } & \multicolumn{3}{|c|}{ Farm-2 } \\
\hline No. of boars & 13 & 7 & 4 & 10 & 6 & 4 \\
\hline No. of sows & 24 & 20 & 19 & 29 & 23 & 15 \\
\hline No. of piglets & 196 & 169 & 152 & 243 & 203 & 99 \\
\hline Piglets from first parity sows, $\%$ & 20 & 22 & 26 & 33 & 37 & 27 \\
\hline $\begin{array}{l}\text { Sows with medium to high PCV2 IPMA } \\
\text { antibody titres, } \%\end{array}$ & 79 & 85 & 89 & 100 & 100 & 100 \\
\hline PWM, \% (n) & $1.5(3)$ & $4.7(8)$ & $9.9(15)$ & $2.1(5)$ & $5.9(12)$ & $26.3(26)$ \\
\hline PMWS-PWM, \% (n) & $1.5(3)$ & $2.4(4)$ & $6.6(10)$ & $0.8(2)$ & $3.0(6)$ & $21.2(21)$ \\
\hline $\begin{array}{l}\text { PMWS-PWM in piglets from primiparous } \\
\text { sows - multiparous sows, } \%\end{array}$ & $2.6-1.3$ & $0-3.1$ & $7.7-6.2$ & $0-1.2$ & $1.3-3.9$ & $3.7-27.8$ \\
\hline PMWS-PWM (Males - Females), \% & $1.0-2.0$ & $3.3-1.3$ & $7.2-5.8$ & $0.8-0.8$ & $2.1-3.7$ & $18.0-26.3$ \\
\hline $\begin{array}{l}\text { Piglets with medium to high PCV2 IPMA } \\
\text { antibody titres at } 3 \text { weeks of age, } \% \text { a }\end{array}$ & 9 & 70 & 26 & 47 & 37 & 23 \\
\hline BW at 21 weeks of age $(\mu \pm S D), \mathrm{Kg}^{\mathrm{a}}$ & $88.2 \pm 10.4$ & $82.9 \pm 12.8$ & $78.4 \pm 15.2$ & $85.2 \pm 10.5$ & $80.2 \pm 10$ & $80.2 \pm 5.6$ \\
\hline
\end{tabular}


Table 2. Longitudinal mixed model estimates for BW evolution.

489

\begin{tabular}{|c|c|c|c|c|}
\hline \multirow[b]{2}{*}{ Covariate/s } & \multicolumn{4}{|c|}{ Confidence Interval $^{\mathrm{a}}$} \\
\hline & Estimate & Lower & Upper & $P^{\mathrm{a}}$ \\
\hline \multicolumn{5}{|l|}{ Genetic background } \\
\hline A vs B & 2.300 & 0.893 & 3.708 & $<0.001$ \\
\hline A vs $\mathrm{C}$ & 4.009 & 2.563 & 5.455 & $<0.001$ \\
\hline C vs B & -1.708 & -3.159 & -0.258 & 0.016 \\
\hline \multicolumn{5}{|c|}{ Genetic background and farm interaction } \\
\hline Farm-1: A vs C & 5.168 & 2.665 & 7.670 & $<0.001$ \\
\hline $\mathrm{C}$ vs $\mathrm{B}$ & -3.185 & -5.685 & -0.686 & 0.004 \\
\hline Farm-2: A vs B & 2.618 & 0.257 & 4.979 & 0.020 \\
\hline A vs $\mathrm{C}$ & 2.850 & 0.373 & 5.326 & 0.014 \\
\hline B farm-1 vs B farm-2 & 2.711 & 0.280 & 5.142 & 0.019 \\
\hline \multicolumn{5}{|c|}{ Genetic background and age interaction } \\
\hline 15 weeks of age ${ }^{b}: A$ vs C & 5.601 & 1.489 & 9.713 & $<0.001$ \\
\hline 21 weeks of age ${ }^{c}: A$ vs B & 4.479 & 0.499 & 8.460 & 0.013 \\
\hline A vs $\mathrm{C}$ & 7.493 & 3.271 & 11.715 & $<0.001$ \\
\hline
\end{tabular}

$490{ }^{\mathrm{a} C o n f i d e n c e ~ i n t e r v a l s ~ a n d ~} P$-values adjusted with the Tukey correction.

$491{ }^{\mathrm{b}}$ Mean weight \pm standard deviation for piglets with $\mathrm{A}$ and $\mathrm{C}$ background were

$492 \quad 54.6 \pm 7.2 \mathrm{Kg}$ and $49.1 \pm 8.6 \mathrm{Kg}$, respectively.

$493{ }^{\mathrm{c}}$ Mean weight \pm standard deviation for piglets with $\mathrm{A}, \mathrm{B}$ and $\mathrm{C}$ background were

$494 \quad 86.6 \pm 10.5 \mathrm{Kg}, 81.5 \pm 11.4 \mathrm{Kg}$ and $79.1 \pm 12.1 \mathrm{Kg}$, respectively. 